\title{
MIGRATION CHALLENGES: TRENDS AND IMPLICATIONS FOR UKRAINE AND COUNTRIES OF EASTERN EUROPE
}

\author{
Tetiana Drakokhrust ${ }^{1}$, Iryna Prodann ${ }^{2}$, Uliana Tkach ${ }^{3}$
}

\begin{abstract}
Transformational processes in the global economy are due to strengthening the integration of national economies, increasing transnationalization, deepening internationalization of production and exchange, are accompanied by the activation of migration challenges. The purpose of the article is to examine and analyse the migration challenges, their development trends and the potential consequences for Ukraine's and countries of Eastern Europe economic potential. To achieve the goal, the study focuses on the following tasks: to consider and analyse the main factors that have a direct impact on the socio-economic development of the country, such as the activation of international mobility of the Ukrainian people, armed conflict in eastern Ukraine, the introduction of a visa-free regime with the $\mathrm{EU}$; to make a socio-economic analysis of migration processes in the countries of Eastern Europe; to consider and analyse the possible (potential) scenario of the development of the impact of migration challenges on the Ukrainian economy; to offer recommendations on mitigating the negative manifestations of the current migration challenges for Ukraine. Methodology. In the process of writing the article, methods of scientific abstraction, observation, synthesis of generalization were used to distinguish key socio-economic factors influencing migration challenges. The information and analytical base for the study of migratory challenges is the monographic works of foreign and domestic economists devoted to international migration, materials and analytical reports of international organizations dealing with migration (International Organization for Migration, International Labor Organization, United Nations Population and Development Commission, World Bank and others), regulatory and statistical data of the state authorities of Ukraine, results of scientific research of the Institute of Demography and Social Research after M. V. Ptukha NASU, Internet resources. The practical significance of the scientific research is to clarify the migration challenges, their development trends and potential implications for the economic potential of Ukraine on the basis of macroeconomic indicators; the likely economic consequences of the introduction of a visafree regime for the European Union for Ukraine and the projected tendencies of migration challenges as proposed scenarios, indicating developers and prospects for forecasting.
\end{abstract}

Key words: migration, migratory challenges, migration processes, economic development, migrants, internally displaced persons, visa-free regime, armed conflict, international migration.

JEL Classification: O15, O10, F22, F63

\section{Introduction}

In the context of the rapid intensification of international mobility of the population of Ukraine, which is taking place in line with the natural globalization of the growth of world migration, the importance of regulating migration processes, giving them an organized, safe and non-conflictual character, is increasing.

Adequate migration policies are needed, on the one hand, to minimize the risks of migration and, secondly, to use a significant positive migration potential in the interest of development. It should be added that the ability of national governments to properly regulate migratory movements is a prerequisite for successful international cooperation, without which migration management, as a multilateral process, is impossible.

Despite this, despite the considerable progress in the development of Ukraine's migration policy, which has been observed in recent years, there is still a lack of clear, focused, integrated regulation of migration.

In addition, the second not less important factor, which has influenced and continues to affect the serious

\footnotetext{
Corresponding author:

${ }^{1}$ Ternopil National Economic University, Ukraine.

E-mail: tanya.drakohrust@gmail.com

${ }^{2}$ Ternopil National Economic University, Ukraine.

E-mail: prodan.iryna@gmail.com

${ }^{3}$ Ternopil National Economic University, Ukraine.

E-mail: ubilynska@i.ua
} 
growth of both international and internal mobility of Ukraine, an armed conflict in the east of Ukraine. The number of victims of the conflict in eastern Ukraine in June 2017 was the highest in the last ten months. According to the UN, 12 people were killed and 57 wounded on the background of the recovery of serious clashes.

As a result of the war, the Ukrainian economy suffered seriously with a reduction of $11.2 \%$ in 2016 and $13.6 \%$ in 2017. According to the World Bank, in 2017, Ukraine's annual GDP per capita amounted to $\$ 2,500$ (at the current exchange rate), compared to about $\$ 4,000$ in 2013. From the outbreak of the conflict in the Donbas in mid-April 2014 and by May 15, 2018, at least 10090 people were killed, referred to in the United Nations 18th report on the human rights situation in Ukraine. The report emphasizes that among the dead in the Donbas - 2777 civilians, 23966 people were injured. The UN emphasizes that this is a conservative estimate, and real numbers are likely to be higher. In addition, according to the press service of the Ministry of Social Policy, as of February 5, 2018, more than 1.5 million people were internally displaced.

And the third most important factor is usually the visa-free regime. On May 11, 2017, the Council of Ministers of the European Union approved for Ukraine a visa-free regime. Then, after signing the official document, on June 11, 2017, Ukrainians were given the opportunity to ride without borders. In an integral form, economic processes are reflected in a variety of financial indicators. The economic consequences of the introduction of a visa-free regime with the EU are no exception in this regard.

However, for some of these effects, such as the impact of the introduction of a visa-free regime on the state of the domestic labour market, it is difficult to provide a clear financial assessment. On the other hand, in some areas, the impact of introducing a visa-free regime with the EU on the state of our country's economy will be quite clearly reflected in changes in Ukraine's balance of payments.

This study will attempt to answer the question whether all these factors have been stimulated by the Ukrainian economy and also to consider the possible (potential) scenario of the development of the impact of migration challenges that dictates our present to the Ukrainian economy.

\section{Trends in migration in Ukraine before and after the deployment of armed conflict}

The large scale of external migration was characteristic of Ukrainian society for a long time after the collapse of the USSR. However, in 2008-2009, the dynamics of migration became weaker. According to an all-Ukrainian study on labour migration in 2005-2008, 1.5 million Ukrainians worked abroad, and in 2010-2012 this figure was 1.2 million.
The decrease was mainly due to the global economic crisis and the decrease in demand for Ukrainian workers in the EU and Russia. In 2005-2008, the most popular countries for Ukrainian labour migrants were Russia, Italy, and the Czech Republic, while in 2010-2012 the main directions were Russia and Poland. For pre-war migration, a more rational approach to choosing a country of destination is characteristic of the accumulated experience over many years and a significant network of migrants. By 2014, most Ukrainian labour migrants came from the western part of the country.

In the period under review, the migration of Ukrainians was of a purely economic nature, unlike, for example, residents of Georgia or the North Caucasus who were forced to flee war or persecution. Prior to the conflict, Ukrainians practically did not apply for refugee status in EU countries.

Trends in migration processes in Ukraine are influenced by socio-economic circumstances. 20132016 were very difficult for the Ukrainian economy. There was a decline in GDP, industrial production, with the exception of some industries. The largest decline is demonstrated machine building and metallurgical industry. Only from 2016 began a slow start improvement of the situation.

Reduction of foreign direct investment, unstable external demand, and substantial reduction of capital investment will allow in the coming years to rely only on domestic demand, whose potential is comparable to in previous years, much weaker. Unfavourable conditions of conducting business and low solvency of the population lead to a reduction in the number of Western companies in the market and not the realization of investment potential in Ukraine (Kulchyczka, 2017).

The current account balance is stable in the negative zone. The overall internal and external state debt of Ukraine continues to increase.

The deficit of the current account of Ukraine's balance of payments in 2013, that is, before the deterioration of the economic situation in 2014-2015, amounted to about 13 billion US dollars. The need of Ukraine's economy for external financing remains high.

The external market gives little prospects. In 2013, as in 2012, Ukraine counted on domestic demand for industrial products production. The formation of domestic demand was more influenced by the dynamics of real wages and retail turnover.

This indicator has a steady tendency to decrease both in 2012 and in 2013. For macroeconomic policy, important is the assessment of macroeconomic indicators characterizing the state of the economy in general (Ioncev, 2007).

Consider the study of the dynamics of the basic macroeconomic indicators of Ukraine with the forecast up to 2017 in Table 1 titled the dynamics of nominal and real GDP for the period of 2007-2015 with a forecast by 2017 (World Development Indicators). 
Table 1

Dynamics of nominal and real GDP for the period of 2007-2015 with a forecast by 2017

\begin{tabular}{|l|c|c|c|c|c|c|c|c|c|c|}
\hline \multicolumn{1}{|c|}{ Types of GDP } & 2007 & 2008 & 2009 & 2010 & 2011 & 2012 & 2013 & 2014 & 2015 & 2017 \\
\hline Nominal GDP (billion USD) & 143 & 180 & 113 & 138 & 163 & 175 & 178 & 135 & 144 & 182 \\
\hline GDP per capita (USD) & 3,07 & 3,886 & 2,454 & 2,99 & 3,562 & 3,82 & 3,91 & 2,98 & 3,19 & 4,079 \\
\hline Real GDP growth (\%) & 7,6 & 2,3 & 14,8 & 4,2 & 5,1 & 0,3 & 0,0 & 7,0 & 0,0 & 4,0 \\
\hline Real GDP growth per capita (\%) & 8,2 & 2,9 & 14,3 & 4,6 & 5,5 & 0,6 & 0,1 & 6,6 & 0,5 & 4,5 \\
\hline
\end{tabular}

Source: (Medium and Long-Term Scenarios for Global Growth and Imbalances. Retrieved from: http://www.oecd.org/berlin/50405107.pdf/)

Table 2

Indicators of the dynamics of the state debt for the period of 2007-2015 with a forecast for 2017

\begin{tabular}{|l|c|c|c|c|c|c|c|c|c|c|}
\hline & 2007 & 2008 & 2009 & 2010 & 2011 & 2012 & 2013 & 2014 & 2015 & 2017 \\
\hline Change in total public debt / GDP (\%) & 1,1 & 10,6 & 14,1 & 10,5 & 3,1 & 3,0 & 4,7 & 20,8 & 7,5 & 1,0 \\
\hline Balance of Payments / GDP (\%) & 2,0 & 3,2 & 8,7 & 7,0 & 4,1 & 6,6 & 6,7 & 11,0 & 7,5 & 4,0 \\
\hline Government debt / GDP (\%) & 12,3 & 20,2 & 34,8 & 39,5 & 36,3 & 36,5 & 40,0 & 60,1 & 62,7 & 58,7 \\
\hline Net government debt / GDP (\%) & 10,1 & 18,6 & 33,8 & 37,2 & 35,5 & 36 & 39,6 & 59,7 & 62,3 & 58,3 \\
\hline
\end{tabular}

Source: Register of Commission Documents

In Table 1 it can be seen that GDP per capita decreased by $7 \%$ in the 2014 year and according to the forecast will resume in 2017 at the level of 2013, there is also sharp fluctuations of the GDP growth rate in the crisis and post-crisis period of 2007-2010 changes to fluctuations with less amplitude.

Table 2 presents the main indicators of the dynamics of the state debt for the period of 2007-2015 with a forecast for 2017.

Consequently, the state debt in Ukraine has sharply increased since 2014 and continues growth. Regarding financing of the general deficit of the state budget, then according to the government, it will amount to at least $2 \%$ of GDP.

At the same time, the expenses of public administration in relation to incomes increased in 2014 almost 2 times in 2013.

Dynamics of projected changes in population, annual rates a natural increase of 1000 people and a net migration rate of 1000 people for Ukraine is presented in Table 3. Appropriate projections were carried out by international experts of the World Bank.
As can be seen from Table 3 to 2050 the population of Ukraine is expected to be reduced to almost 10 million people. In Ukraine, the indicator of net migration is expected to be negative.

Dynamics of projected changes in working age (according to age the range accepted for international assessments - 15-64 years) of the population at 1000 persons for Ukraine are presented in Table 4. As you can see, in Ukraine a stable decrease in the number of representatives of the corresponding age group is expected.

Between 1991 and 2012, the total population fell by more than 7 million people as a result of a sharp decline in fertility and a negative balance of migration. The study argues that this trend will continue, and the total population will be reduced by another 10 million by 2050 . In addition, by 2050 , it is projected that almost half of the population will be over 45 years old. The share of persons aged 60 and over will increase more by 2050 by 1.5 times, and persons aged 80 and over for the same period will increase 3.4 times.

Table 3

Projected changes in the total population of Ukraine

\begin{tabular}{|l|c|c|c|c|}
\hline \multicolumn{1}{|c|}{ Changes } & $2015-20$ & $2025-30$ & $2035-40$ & $2045-50$ \\
\hline Total population at the end of the period & 43164 & 39842 & 36554 & 33658 \\
\hline Change in population during the period & -1482 & -1718 & -1581 & -1426 \\
\hline Annual natural growth rate per 1000 people & $-6,57$ & $-8,25$ & $-8,25$ & $-8,07$ \\
\hline Net migration rate per 1000 people & $-0,18$ & $-0,20$ & $-0,21$ & $-0,23$ \\
\hline
\end{tabular}

Source: World Bank staff calculation based on data from IMF Balance of Payments Statistics Yearbook 2013 and data releases from central banks, national statistical agencies, and World Bank country desks

Table 4

Projected changes in working age (15-64 years) of the population average (per 1000 people) in Ukraine

\begin{tabular}{|c|c|c|c|}
\hline $2015-20$ & $2025-30$ & $2035-40$ & $2045-50$ \\
\hline-2401 & -1324 & -1268 & -1719 \\
\hline
\end{tabular}

Source: Migration Profiles - Common Set of Indicators. Retrieved from: http://esa.un.org/MigGMGProfiles/MPCSI.htm 
The answer to the negative trends of economic development has become the formation and functioning of large-scale flows of external labour migration. This process in the existing realities has more positive effects for Ukraine than the negative, and there is a kind of fuse to achieve excessive regional migration asymmetry in the country (Timofeiev, 2013).

According to the results of a study conducted in 2012, the State Statistics Service of Ukraine and Ptoukha Institute for Demography and Social Studies of the NAS of Ukraine, for the period of 2010-2012 1.2 million Ukrainians (3.4\% of the population aged 15 to 70 years old were working or looking for work abroad. The main areas of employment were: construction (46\%), home care (18\%), and agriculture (11\%), wholesale and retail trade (9\%), industry (4\%), hotel and restaurant sector (4\%), transport sector (4\%), other (4\%). The majority of Ukrainians travelled to the neighbouring countries - Russia (43\% of migrants), Poland (14\%), Hungary (2\%), and a number of European countries (Czech Republic (13\%), Italy (13\%), Spain (5\%), Portugal (2\%) and other countries (8\%)).

The volume of international labour migration in Ukraine for 2015 was as follows results of the research of IOM 688000 persons, including 423800 long-term (migration not less than 1 year) and 264400 short-term migrant workers. In addition, about 310000 people expressed their intention to migrate to the next 12 months, which is about $45 \%$ of the current volume. Ukraine's internal mobility is twice as large as the number of external labour migrants (1 643000 people).

The total volume of internal migration in 2014 was $9 \%$ of the economically active population in Ukraine. The annual pace of domestic mobility is expected to increase by about 50\% in 2015-2016 (International Organization for Migration (IOM)).

According to the data of this survey, the volumes of migrations are smaller in comparison with the data of the State statistics and IDDS named after M.V. Ptoukha of the National Academy of Sciences, obviously, this is due to a decrease in the level of openness of respondents in crisis conditions.

In 2013-2014, there was a new wave of migration emerges in Ukraine - internally displaced persons from temporarily occupied territory and districts antiterrorist operation. According to the State Migration Service, as of December 31,2014, the total number of such persons, taking into account displaced within the Donetsk and Luhansk oblasts was close 630 thousand people (Lukyanenko, 2014).

At the end of March 2017, their number increased to 1065 thousand people. According to the Ministry of Social Policy, their number exceeded 1.6 million persons in March 2017. According to the UN, a number of refugees and internally displaced persons in Ukraine (including those who moved to other regions Ukraine, and those who left the country) is 1.8 million people (Libanova, 2006).
Negative trends of economic development of Ukraine have caused the formation and development of largescale flows of external labour migration.

Mostly, Ukrainian citizens work in the EU countries (mainly in Poland, the Czech Republic, and Italy), as well as in Russia. For most of the period of Independence, foreign labour migration was the largest in terms of volume migration movements. However, the annexation of the Crimea and the beginning of hostilities on Eastern Ukraine caused the formation of flows of internally displaced persons, which today become comparable with flows of external labour migration.

\section{Socio-economic analysis of migration processes in the countries of Eastern Europe}

Considering the role and importance of international migration in the demographic development of countries, we note that it can grow for most countries as the subject to increase the volume of immigration or emigration, and the extent of temporary labour migration and forced migration. Consider the situation in three Eastern European countries for which complete data are available, and Ukraine.

The dynamics of the projected changes in the population, the annual rate of natural increase per 1000 people and the net migration rate per 1000 people for the countries of Eastern Europe are presented in the table below.

As can be seen, the annual rate of natural growth per 1000 people in Poland and the Czech Republic is approximately the same, with the population in Poland is almost 7 times larger.

The worst indicator at the end of the period is expected in Bulgaria. The total population is projected to decline substantially in all countries in this group, except the Czech Republic. Annual rates of natural growth per 1000 people in the Czech Republic are the smallest, although they remain negative.

Consider the dynamics of the projected changes in the population of able-bodied age population (15-64 years) population per 1000 people, which is presented in the following table.

According to Table 6, in the second five-year period, an improvement is expected with a further sharp rise in the rate of decline, with the best expected changes expected in the Czech Republic.

Over the past decade, the role of migrants in the world has grown. According to the World Bank, migrants earn an average of about $\$ 2.6$ trillion a year, which puts the migration economy in sixth place in the world - before Britain and after the French economy. Many studies have shown that the effectiveness and efficiency of foreign migrants are much higher than indigenous people. Over the past 20 years, many developed countries have doubled the number of immigrants. In the United States, their number has reached almost 46 million, or 
Table 5

Predicted changes in total population

\begin{tabular}{|c|c|c|c|c|}
\hline & $2015-20$ & $2025-30$ & $2035-40$ & $2045-50$ \\
\hline \multicolumn{5}{|c|}{ Bulgaria } \\
\hline Total population at the end of the period & 6827 & 6213 & 5611 & 5077 \\
\hline Change in population during the period & -285 & -314 & -291 & 263 \\
\hline Annual natural growth rate per 1000 people & $-6,76$ & $-8,28$ & $-8,39$ & $-8,17$ \\
\hline the net migration rate per 1000 people & $-1,44$ & $-1,57$ & $-1,74$ & $-1,92$ \\
\hline \multicolumn{5}{|c|}{ Czech Republic } \\
\hline Total population at the end of the period & 10924 & 11053 & 11101 & 11218 \\
\hline Change in population during the period & 147 & 34 & 34 & 61 \\
\hline Annual natural growth rate per 1000 people & $-0,05$ & $-2,09$ & $-2,10$ & $-1,60$ \\
\hline the net migration rate per 1000 people & 2,77 & 2,72 & 2,71 & 2,71 \\
\hline \multicolumn{5}{|c|}{ Poland } \\
\hline Total population at the end of the period & 38158 & 37448 & 35840 & 34079 \\
\hline Change in population during the period & -264 & -476 & -873 & -867 \\
\hline Annual natural growth rate per 1000 people & $-0,13$ & $-2,33$ & $-4,61$ & $-4,80$ \\
\hline the net migration rate per 1000 people & $-0,20$ & $-0,20$ & $-0,21$ & $-0,22$ \\
\hline
\end{tabular}

Source: World Bank staff calculation based on data from IMF Balance of Payments Statistics Yearbook 2013 and data releases from central banks, national statistical agencies, and World Bank country desks

Table 6

Projected changes in the population of able-bodied age (15-64 years), average (per 1000 people)

\begin{tabular}{|l|c|c|c|c|}
\hline \multicolumn{1}{|c|}{ Country } & $2015-20$ & $2025-30$ & $2035-40$ & $2045-50$ \\
\hline Bulgaria & -310 & -213 & -281 & -251 \\
\hline Czech Republic & -200 & -32 & -190 & -124 \\
\hline Poland & -1381 & -523 & -798 & -1626 \\
\hline
\end{tabular}

Source: Migration Profiles - Common Set of Indicators. Retrieved from: http://esa.un.org/MigGMGProfiles/MPCSI.htm

about $15 \%$ of the employed population. The absence of a positive dynamics of the growth of the number of migrants is evident in Ukraine.

Thus, the preservation of migration growth will not only ensure sustainable population growth in the coming decades but will also help to slow down the aging population and smooth the age structure of the population.

\section{Probable economic consequences of the introduction of the visa-free regime of the European Union for Ukraine}

Most expert forecasts about the migration situation in Ukraine put forward hypotheses regarding the general tendencies of the development of migration processes. According to researchers, the introduction of a visa-free regime with the EU and the military-political situation in Ukraine and in the countries of the world can also have a significant impact on the changing nature of migration movements of the population.

Since the existing system of visa-free travel does not give the right to employment of Ukrainians abroad, it was determined that the introduction of a visa-free regime would not be significantly affected by the scale of migration of skilled personnel but could lead to an increase in the detection of unregulated Ukrainian migrants in the EU.
At present, Ukrainians who are illegally staying in the EU and the Schengen area are mostly identified with visas or residence permits that expired, rather than those who illegally crossed the border and did not have any work permits. In 2016, about 27 thousand Ukrainian citizens with unregulated status were found in the EU, which is considerably less than the number of persons who used legal means of migration (Kompleksnyj demografichnyj prognoz Ukrayiny na period do 2050 r.). Most Ukrainians were found during an illegal stay in Poland (17 445 people), Hungary (3620 people), Czech Republic (1550 people), Germany (2270 people).

Instead, it is expected that the introduction of a visafree regime will reduce the number of asylum seekers from Ukraine to the EU, as the status of asylum seeker will be less and less used by migrants as a possibility to legally stay in the EU for a term of up to three months.

It should be noted that in 2014-2015, there was an increase in flows of asylum seekers from Ukraine to the EU due to military aggression in the East of Ukraine and the annexation of Crimea. In 2016, for the first time since the conflict began, the growth of Ukrainian asylum seekers in the EU declined: 12475 applications were registered, which is $43 \%$ less than in 2015 . The main factor that is likely to affect the number of asylum seekers from Ukraine to the EU may be a high level of refusal, which is explained by the possibility 
Vol. 5, No. 2, 2019

Table 7

Scenarios of the impact of migration challenges on the Ukrainian economy

\begin{tabular}{|c|c|c|}
\hline Developer & $\begin{array}{l}\text { Perspective } \\
\text { forecasting }\end{array}$ & Predictable tendencies of migration challenges \\
\hline $\begin{array}{l}\text { Ukrainian Centre } \\
\text { for Social Reforms }\end{array}$ & 2050 & $\begin{array}{l}\text { Scenario 1: Medium option. Termination of the reduction of the intensity of contacts and a positive } \\
\text { migration balance with the countries of the former USSR, the second wave of repatriation of deported } \\
\text { peoples; increased volumes of arrival from Europe and America due to the increase in the number of } \\
\text { representative offices of foreign companies; development of the flow of immigration to Ukraine from } \\
\text { emerging countries. } \\
\text { Scenario 2: High Version. Accelerated level of population growth in Ukraine; ahead of the development } \\
\text { of the Ukrainian economy compared to CIS countries and Eastern Europe; a positive migration balance } \\
\text { throughout the period; growth of immigration from EU, CIS, Africa, and Asia. } \\
\text { Scenario 3: Low Version. The growth of emigration of skilled personnel to EU countries; the growth } \\
\text { of emigration to the Russian Federation of citizens of Russian descent; low level of consolidation of } \\
\text { migrants from Afro-Asian countries; a positive migration balance will be observed in 2030-2035, after } \\
\text { which the departure to the Russian Federation is intensified. } \\
\text { Scenario 4: Low-end version. Lack of state policy on attracting migrants; an economic downturn; } \\
\text { growth of emigration to the EU and CIS countries; reduction of immigration from Afro-Asian } \\
\text { countries; a negative migration balance throughout the period. }\end{array}$ \\
\hline $\begin{array}{l}\text { Yaroshevych M. } \\
\text { Lasinskaya M. } \\
\text { Betliy O. } \\
\text { Center for Oriental } \\
\text { Studies, Poland }\end{array}$ & 2050 & $\begin{array}{l}\text { Scenario 1: Low Scenario (Best). The growth of GDP in Eastern European countries by 1\%, in EU } \\
\text { member states - by 4\%; the growth of emigration from Ukraine to the EU countries by } 2020 \text { to } 1.4 \text { million } \\
\text { people, after which the gradual reduction of the number of emigrants to } 0.9 \text { milli on people in } 2050 \text {. } \\
\text { Scenario 2: Average scenario (realistic). The growth of GDP in Eastern European countries by } 0 \% \text {, in } \\
\text { EU member states - by 2\%; the sharp increase in emigration from Ukraine to the EU countries by } 2019 \\
\text { to } 1.6 \text { million, followed by a gradual reduction of the number of emigrants to } 1 \text { million in } 2050 \text {. } \\
\text { Scenario 3: High Scenario (Worst). GDP reduction in Eastern European countries by } 2 \% \text {, GDP growth } \\
\text { in EU member states by 0\%; the gradual growth of emigration from Ukraine to the EU countries to } 1.9 \\
\text { million people in } 2050 .\end{array}$ \\
\hline $\begin{array}{l}\text { Ukrainian Institute } \\
\text { of Public Policy }\end{array}$ & 2020 & $\begin{array}{l}\text { Scenario 1: Unmanaged Migration (Status Quo). The growth of population due to migration exchange; } \\
\text { increase in the share of illegal migrants; the deterioration of the criminogenic situation and the } \\
\text { emergence of ethnic conflicts due to the influx of migrants from the countries of Central and Eastern } \\
\text { Asia; increasing pressure on the labour market. } \\
\text { Scenario 2: Managed Migration. Immigrant skills development; improvement of the economic situation } \\
\text { of the country by attracting and efficient allocation of labour resources. }\end{array}$ \\
\hline
\end{tabular}

Source: Official site of the State Statistics Service of Ukraine

for citizens who have been prosecuted in temporarily occupied territories to live safely in the rest of Ukraine (Malynovska, 2016).

In 2016, the share of refusals increased from $70 \%$ to $75 \%$ (from 6630 failures in 2015 to 8785 failures in 2016). Often, Ukrainians sought refuge in countries with a large Ukrainian Diasporas: Italy, Spain, Germany, and Poland. On the other hand, introducing a visafree regime creates more favourable conditions for arriving in EU countries and applying for asylum for those internally displaced persons who were unable to integrate in Ukraine (Korniyenko, 2013).

The impact of the political situation on the intensity of migratory flows in Ukraine is extremely difficult to predict even in the near future. It is possible to expect a further reduction of the scale of the departure of Ukrainians to Russia, especially from the western territories, and the reorientation of migration flows to the EU. Nevertheless, migratory flows to the Russian Federation will remain significant due to the simpler mechanism of obtaining work in comparison with the EU, the knowledge of Ukrainians by the Russian language, cultural and territorial proximity.

\section{Conclusions}

Modern migration processes in Ukraine were shaped by influence socio-economic development and geopolitical transformations of the latter a decade. The largest migration flows are external labour migration, movement of internally displaced persons and forced migration for borders of the country from the regions of combat operations.

Events in the east of Ukraine influenced not only the internal state redistribution of the populationbut also on the course of external labour migration of Ukrainians. In the period from 2014, the number of Ukrainian labour migrants grew, they increasingly began to choose for employment EU countries, not the Russian Federation. However, the share increased Ukrainian citizens who work abroad without having an official one legal status, the consequence of which is the violation of their rights and freedoms. Provided further confrontations in eastern Ukraine can be expected to continue.

As for the introduction of a visa-free regime with the EU for the development of the Ukrainian labour 
market, it is worth paying attention to the following points. First, the above-mentioned regime opens up more promising opportunities for finding work for Ukrainian citizens and organizing training for Ukrainian youth in European higher education institutions. Secondly, taking into account the attractiveness of the European labour market for Ukrainians, one can expect, in the near future, to increase the number of Ukrainian citizens who go to work and study in the EU.

At the same time, exit from Ukraine will not have low-skilled workers; we believe there is a very negative impact on the development of the Ukrainian economy. However, an increase in labour migration to European countries of highly skilled workers, as well as young people, if it does not return to Ukraine after training, can nevertheless negatively affect the development of the national economy if Ukrainian enterprises lack highly skilled workers.

Therefore, we believe that in order to prevent such a course of events, Ukrainian enterprises will need to raise wages for their future specialists and create better conditions for attracting young people to diverse enterprises.

In addition, it should be remembered that the introduction of a visa-free regime with the EU for Ukrainian citizens under the current conditions automatically becomes a sphere of hybrid aggression against Ukraine. Indirectly, this is evidenced by the reaction of Russian politicians and the media to this event. Therefore, this direction of international relations should become at least an object of monitoring of the relevant Ukrainian think tanks.

In an integral form, economic processes are reflected in a variety of financial indicators. It is no exception in this regard and the economic consequences of the introduction of a visa-free regime with the EU. However, for some of these effects, such as the impact of the introduction of a visa-free regime on the state of the domestic labour market, it is difficult to provide a clear financial assessment. On the other hand, in some areas, the impact of introducing a visa-free regime with the EU on the state of our country's economy will be quite clearly reflected in changes in Ukraine's balance of payments.

As regards the scenarios of the impact of migration challenges on the Ukrainian economy, factors of influence are the demographic situation, unemployment rate, wages, migration policy, as well as the political situation in Ukraine and in the world. Each of these factors affects the dynamics of the number of migrant workers.

So, in particular, the reduction and aging of the population in the $\mathrm{EU}$, the presence of hidden unemployment in Ukraine, the problems of youth employment after education, the wage increase is 3-5 times in the EU countries compared to Ukraine, and the highest wages in all countries-residents of Ukrainian migrants, lack of concrete measures in Ukraine aimed at the repatriation of Ukrainians, and the presence of such measures in foreign countries, political instability in Ukraine - all these factors contribute to increasing quantity of migrants to the EU.

We emphasize that the experience of the Czech Republic, Poland, and other Eastern European countries is particularly valuable in creating conditions for healthy competition, including protection of property rights, adoption of relevant laws. In addition, the practice of these countries shows that the strategy of modernization policy for all transition countries should consist of concentrating all national resources on the development of certain potentially competitive industries, hence the selective targeted state influence on these processes through financing, variation in tax rates, creation of a legal regime and differentiation of social measures.

The tendency to leave Ukraine is observed in all categories of the population, experts say. The main reason - a difficult economic situation, which contributes to the increase in the number of people willing to go to work abroad. Emigration from Eastern European countries differs by at least two peculiarities. First, it has a largely ethnic or ethnocultural basis. Residents of Poland and Romania, who moved to Germany in the mid-1990s, were mostly ethnic Germans, and many of those who moved to Hungary were ethnic Hungarians. Similarly, from the former Soviet Union in the 1990s, mainly Germans and Jews were leaving, at least Finns, Greeks, Czechs, and Poles, and from the CIS countries to Russia during this period, usually came ethnic Russians and Russian-speakers.

Thus, at the moment, the greatest influence on the further development of the impact of migration challenges on the Ukraine's economy has such a factor as the political situation in the country. The migration policy of the highly developed countries of the European Union is aimed at attracting immigrants, including Ukrainians, which contributes to the increase of migration.

However, all measures of foreign countries will not matter for the Ukrainian emigrant, if, as an alternative, he will have prospects in the Motherland. If after stabilizing the political situation in Ukraine, the country's economy will develop in such a way that a Ukrainian migrant will be able to receive decent wages to ensure normal living conditions for his family, social guarantees, favourable conditions for doing business, he will not need to seek low-skilled work or work with a high level of injury abroad. Particularly promising, in this direction, is the development of measures for the return to their homeland of young people studying abroad, and can use the experience gained in Ukraine to conduct business in Ukraine. 


\section{References:}

Doslidzhennya ta dialog shhodo polityky u sferi migraciyi i groshovykh perekaziv v Ukrayini (2016). [International organization of Migration (IOM), Representation in Ukraine]. Retrieved from: http://iom.vh.lucky.net/sites/ default/files/mom_migraciya_yak_chynnyk_rozvytku_v_ukrayini.pdf (in Ukrainian)

Korniyenko, O. O. (2013). Migracijna polityka Ukrayiny v systemi globalnogo rozvytku svitovoyi ekonomiky [Management of a modern city]. Kyiv, issue 3-4/7-12(51-52), 51-56. (in Ukrainian)

Libanova, E. M. (2006). Kompleksnyj demografichnyj prognoz Ukrayiny na period do 2050 r. [Ukrainian Center for Social Reforms]. Kyiv, 138 p. (in Ukrainian)

Kulchyczka, K., Sushko, I. (2017). Nevregulovana i vymushena migraciya z Ukrayiny do YS pered otrymannyam bezvizovogo rezhymu: mozhlyvi naslidky ta ochikuvannya [Europe without boundaries]. Kyiv, 108 p. (in Ukrainian) Lukyanenko, D. G., Poruchnyk, A. M. (2014). Mizhnarodna ekonomika: pidruchnyk [International economics: Textbook]. Kyiv: KNEU, 762 p. (in Ukrainian)

Malynovska, O. (2016). Mihratsiia v Ukraini: fakty i tsyfry [Migration in Ukraine: data and statistics]. Kyiv, 32 p. (in Ukrainian)

Ioncev, V. A. (2015). Svit u dzerkali mizhnarodnoyi migraciyi [Scientific series: International migration of population: Russia and modern world]. Moscow, 215 p. (in Ukrainian)

Timofeiev, A. (2013). Problemy zovnishnoi trudovoi mihratsii v Ukraini: suchasni tendentsii [Synopsys: text, context, media]. Kyiv, 9 p. (in Ukrainian)

Valentey, D. I. (1985). Demograficheskiy entsiklopedicheskiy slovar [Demographic Encyclopedic Dictionary]. Moscow: Sov. entsikl. (in Russian)

World Development Indicators. Retrieved from: https:// data.worldbank.org/country/UA?locale=uk (in Ukrainian) 